\title{
27.3. ISOTOPIC DATING OF ALBORAN "BASEMENT"
}

\author{
R. H. Steiger and U. Frick, Laboratory for Isotope Geochemistry and Mass Spectrometry, \\ Eidg. Technische Hochschule, Zurich, Switzerland
}

The large piece of metamorphic rock caught in the drillbit (Sample 13-121-24 CC-A1) was cut in half. One half was made into a thin-section; the other was sent for isotopic dating to the Laboratory for Isotope Geochemistry and Mass Spectrometry, Swiss Federal Institute of Technology, Zurich. This rock is a cordierite-biotite-feldspar hornfels. However, there is considerable evidence of retrograde metamorphism, whereby the primary metamorphic minerals were altered to sericite, chlorite, and actinolite.

Biotite was separated out. Its potassium content was determined by both the isotope dilution and the atomic absorption methods. The argon content was determined in a Nier-type mass spectrometer by the peak height method. The accuracy and precision of this method is comparable to that of the isotope dilution method as verified by measuring the USGS interlaboratory standard muscovite P 207. The analytical results are shown by Table 1 .
TABLE 1

Radiometric Data of Alboran Basement Sample

\begin{tabular}{ll}
\hline \multicolumn{1}{c}{ Mineral } & \multicolumn{1}{c}{ Biotite } \\
\hline K, by isotope dilution & $8.14 \%$ \\
K, by atom-absorption & $7.80 \%$ \\
rad. A 40, cc STP & $(5.20 \pm 0.10) \times 10^{-6}$ \\
Air argon & $51.5 \%$ \\
\hline
\end{tabular}

From these data we compute an age of $16 \pm 1$ million years. The possibility includes the uncertainty caused by the correction of the rather high air argon content. We emphasize that only one sample was analyzed. As the biotite K-Ar ages are easily affected by thermal or regional metamorphism, we have to interpret the age of 16 million years as the minimum age (cooling age) for the last metamorphic event in this particular area.

\subsection{TRACE-ELEMENT COMPOSITION OF ALBORAN BASIN "BASEMENT"}

\author{
J. R. Cann, School of Environmental Sciences, University of East Anglia, Norwich, England
}

Sample 13-121-24 CC-A1 was sent for trace-element analysis to the University of East Anglia, Norwich, England. This sample is a cordierite-biotite-feldspar hornfels and may represent the basement at Site 121 . The analytical results give: Rb 325 ppm, Sr 1350 ppm, Y 20 ppm, Zr 200 ppm, and $\mathrm{Nb} 6.5 \mathrm{ppm}$. Although this is a metamorphic rock of amphibolite facies, its trace-element composition bears considerable resemblance to that of andesitic volcanics behind island arcs. Further investigations are necessary to determine if this similarity is purely coincidental.

\subsection{COMMENTS ON ALBORAN BASIN "BASEMENT" SAMPLES}

K. J. Hsü, Geologisches Institute, Eidg. Technische Hochschule, Zurich, Switzerland

W. B. F. Ryan, Lamont-Doherty Geological Observatory of Columbia University, Palisades, New York

\section{INTRODUCTION}

We are not completely certain if we reached the acoustic basement at Site 121, or if we have only sampled the basal conglomerate of the Neogene sedimentary sequence (see Chapter 3). The acoustic basement was believed to lie some 0.9 second below the bottom. Core 24 at 867 meters subbottom could be anywhere between 0.6 and 0.9 second (assuming an interval sound-velocity of 3.0 and $2.0 \mathrm{~km} / \mathrm{sec}$ respectively). However, we are certain that an unfossiliferous sedimentary breccia is present beneath the upper Miocene Tortonian ooze. Some of the fragments described this chapter are clasts in this breccia. On the other hand, we suspect that the $6-\mathrm{cm}$-long piece jammed in the bit orifice is 